\title{
Religious Affiliations and Ethical Opinions of Students at Xavier University School of Medicine, Aruba
}

\author{
${ }^{1}$ Gabriel Andrade, ${ }^{2}$ Saud Qureshi, ${ }^{3}$ Saleh Khasawneh, ${ }^{4}$ Alladin Kawaiah, ${ }^{5}$ Joseph Sarra
}

\begin{abstract}
Xavier University School of Medicine, Aruba, is an offshore medical school located in the Dutch Caribbean. Most of its students come from the United States and Canada. Yet, they are immensely diverse in their religious affiliation. A study was conducted with students, asking them what their religious affiliation is. Then, they were presented with a series of hypothetical cases dealing with abortion, in vitro technology, embryonic stem cells, and euthanasia. They were asked to give their moral evaluation. The results came out showing that, as a general trend, respondents form their ethical opinions in the medical field, independently of the doctrines of their religious affiliations.
\end{abstract}

Keywords: Abortion, Euthanasia, Medical ethics, Religion.

How to cite this article: Andrade G, Qureshi S, Khasawneh S, Kawaiah A, Sarra J. Religious Affiliations and Ethical Opinions of Students at Xavier University School of Medicine, Aruba. J Postgrad Med Edu Res 2018;52(3):128-134.

Source of support: Nil

Conflict of interest: None

\section{INTRODUCTION}

The academic study of ethics has been traditionally divided in two areas: prescriptive and descriptive ethics. Most scholars devote attention to the first area. This is even more so in the realm of medical ethics. Ethicists are interested in informing about how the world should be, i.e., prescribing. They discuss questions, such as "What is right?" and what is the right course of action in specific situations.

Much philosophical discussion has taken place around the question of whether or not ethical prescriptions can be derived from descriptions. This is technically known as the "is-ought" problem. Enlightenment philosophers, such as David Hume, claimed that "ought" cannot be derived from "is," and therefore, ethics can never be about facts. ${ }^{1}$ In the 20th century, philosopher GE Moore further

\footnotetext{
${ }^{1}$ Lecturer, ${ }^{2-5}$ Student

${ }^{1}$ Department of Behavioral Sciences, Xavier University School of Medicine, Oranjestad, Aruba

${ }^{2-5}$ Department of Ethics and Behavioral Sciences, Xavier University School of Medicine, Oranjestad, Aruba

Corresponding Author: Gabriel Andrade, Lecturer, Department of Behavioral Sciences, Xavier University School of Medicine Oranjestad, Aruba, e-mail: gabrielernesto2000@gmail.com
}

reinforced this notion, with his so-called open question argument. ${ }^{2}$ In Moore's reasoning, ethical statements, such as "Rape is wrong" are not facts, as there is no possible way such a statement can ever be empirically proven.

This philosophical attitude promoted the idea that ethics should be entirely prescriptive. Yet, the field of descriptive ethics remains very important. For, ethics is not just about what is objectively right and wrong, but also about what people think is right and wrong. Whereas prescriptive ethics attempts to decide whether a given action is moral or not (say, abortion), descriptive ethics is about studying how different people come to believe whether a given action is right or wrong.

When it comes to medical education, the realm of descriptive ethics is very important. Medical educators must be aware that medical students may bring in many previous moral conceptions that may differ from the traditional ethical understandings of the medical profession. In fact, it may even be that, prior to formal education in medical ethics, students may have varying ethical opinions regarding particular scenarios, depending on their socioeconomic, cultural, ethnic, and national background.

Throughout human history, religion has played a major role in the formation of ethical opinions. Karl Jaspers coined the term "Axial Age" to describe the period, during which, major religious teachings were developed, and as a result, they have influenced ethical opinions ever since. ${ }^{3}$

Offshore medical schools in the Caribbean offer a great opportunity for the descriptive study of ethics and its relationship to religion. Students of these schools come from diverse religious backgrounds (far more represented than in North American schools). This is especially the case at Xavier University School of Medicine in Aruba, as Catholics, Protestants, Muslims, Atheists, Hindus, Sikhs, and Buddhists are represented among students. The present study sought to investigate the relationship between religious affiliation and ethical opinions in two specific areas that are immensely important in medical ethics: abortion and euthanasia.

\section{MATERIALS AND METHODS}

For the purposes of the current research, a questionnaire made up of 15 questions was designed. This questionnaire met the typical ethical requirements of informed consent, 
confidentiality and anonymity, and it was previously reviewed by Xavier University School of Medicine's Research Committee. In order to ensure anonymity and confidentiality, questions were asked through Survey Monkey software, so researchers never knew a particular subject's answer, as they were never encountered face-toface. Researchers only approached subjects with consent forms, and once these were signed, they were sent the link for the research questionnaire.

We worked with two main variables: religious affiliation and ethical opinions, foreseeing that religious affiliation would be the independent variable, and ethical opinions the dependent variable. For the religious affiliation variable, one close-ended question was asked: "What is your religious affiliation?" including the world's major religions (Catholic, Non-Christian Catholic, Jew, Muslim, Hindu, Sikh, Buddhist, Atheist, Other) as options.

For the dependent variable (ethical opinions), we further divided it into two categories that are essential in medical ethics: abortion (and related topics) and endof-life decisions (and related topics). For each of these categories, close-ended questions were also asked. They presented physicians acting in hypothetical scenarios; subjects were asked if the doctor acted ethically, and respondents had the option of answering "Yes," "No," and "Not sure."

Xavier University School of Medicine in Aruba has a student population of around 150 students. For the purpose of this research, our sample was 57 subjects. Although not entirely representative (due to the fact that some arrangements had to be made in order to collect the data), this is a sufficiently large sample in order to make a meaningful study of the variables in the population. Data were recollected over a period of 3 months.

\section{RESULTS}

As expected from a school that accepts students from various nationalities and ethnic backgrounds, there is significant religious diversity among the subjects of the sample; $26 \%$ are non-Catholic Christians, $16 \%$ are Muslim, $20 \%$ are Catholic, $10 \%$ are Atheists, $15 \%$ are Hindus, $12 \%$ are Sikhs, and $1 \%$ are Buddhists. We present the results of the independent variable, in seven groups, according to each religious category.

\section{Non-Catholic Christians}

This group is almost entirely made up of Protestants, but we decided to label it "Non-Catholic Christians" because there was one Russian Orthodox respondent. When presented with a hypothetical case of a woman into her 4 th week of pregnancy, who decides to have an abortion not giving details for particular reasons, $60 \%$ of subjects in this group answered they had no ethical objections to this, $27 \%$ presented ethical objections, and $13 \%$ were not sure.

As opposed to Catholics, Protestants and Orthodox do not have a centralized authority that dictates religious doctrine, so there is far more fluidity when it comes to ethical beliefs. However, despite the fact that this varies across denominations, most non-Catholic churches believe personhood begins once the egg is fertilized, as the soul enters the body at that exact time, therefore, abortion is wrong, because it is the immoral killing of a person. Yet, more than half of the subjects' response does not match this doctrinal teaching.

When presented with a hypothetical case of a raped woman getting an abortion into her 4th week of pregnancy, $87 \%$ of respondents answered they had no ethical objections to this; $0 \%$ claimed it was ethically wrong, and $13 \%$ were not sure. Thus, $60 \%$ of non-Christian Catholic subjects approved abortion in normal circumstances, but $87 \%$ approved it in rape cases. This discrepancy between the first and the second case is not entirely surprising. Opinions about abortion vary in populations, but various surveys confirm that, when it comes to rape, people in general tend to have a higher level of moral tolerance in abortion for rape victims. ${ }^{4}$

The same results come up when presented with a scenario in which the pregnancy is terminated in order to save the mother's life (in the hypothetical case, a woman with endometrial cancer has her uterus removed, and as a result, the fetus dies): $87 \%$ approved, $0 \%$ disapproved, and $13 \%$ were not sure.

About $20 \%$ of subjects in this group opposed in vitro fertilization, if that implies discarding embryos, $73 \%$ approved it, and $6 \%$ were not sure. This proves to be mildly inconsistent with the previous opinions on abortion. If the embryo is believed to be a person with an intrinsic right to live, then in vitro fertilization should be opposed, as embryos are discarded. Yet, among nonCatholic Christians, 27\% opposed abortion, but only $20 \%$ opposed in vitro fertilization.

About $53 \%$ of this group approved the use of embryonic stem cells (even if that leads to discarding embryos) to potentially treat diseases, such as Parkinson's; $13 \%$ opposed it, and 33\% were not sure. Again, some inconsistencies come up. If embryos are considered to be persons with intrinsic rights, then discarding them should be considered unethical, whether it is in vitro fertilization or in embryonic stem cell therapy and research. Yet, there are more ethical objections to one case than the other.

When it comes to euthanasia, non-Catholic Christian subjects were more conservative. When presented with the case of a doctor who assists a patient in suicide because the patient feels his life is miserable, and asks the doctor to end his life, $13 \%$ answered it is morally 
acceptable, $73 \%$ responded it is morally unacceptable, and $13 \%$ were not sure.

Interestingly, among non-Catholic Christian subjects, there was even more opposition when presented with the case of a mortally wounded soldier in a battlefield with no hospitals nearby, a military surgeon administers morphine to relieve his pain, and the patient dies as a result. About $87 \%$ of respondents claimed this is unethical, $6 \%$ claimed this is ethical, and $6 \%$ were not sure. On the surface, this scenario seems very similar to the case of euthanasia presented previously. But, in fact, there is an important moral difference: in the case of euthanasia, the doctor deliberately seeks the death of the patient, whereas in the case of morphine administration, the doctor does not seek the death of the patient. This is an important moral distinction, which would make the second case less objectionable than the first case. Yet, respondents in this group morally condemned the second case more than the first case.

\section{Catholics}

About $82 \%$ of Catholic subjects accepted abortion in the 4 th week of pregnancy, $18 \%$ opposed it, and $0 \%$ were not sure. This is a very surprising result. Catholics, as opposed to Christians of other denominations, do have a centralized authority that dictates religious doctrine (the Magisterium). And, this doctrine unmistakably states that abortion is a grave ethical violation. Numerous Church Councils and Papal Encyclicals have made this teaching very clear. ${ }^{5}$

This teaching hinges on the belief that the soul enters the body upon the moment of fertilization, and therefore, embryos are persons with full natural rights. This position on full personhood prevents Catholic doctrine from endorsing any type of abortion, even in the case of rape. The rationale is that, while rape is a great evil, it would be an even greater evil to kill an innocent person. Within Catholicism, there are some groups that lobby for the ethical approval of abortion (so-called Pro-Choice Catholics), but they remain on the fringes, and have no real ecclesial power. ${ }^{6}$

Yet, these Catholics who have no moral objections to abortion seem to be highly represented in our sample of medical students. As previously stated, $82 \%$ of Catholic subjects accepted abortion in normal circumstances, and $100 \%$ had no objections to raped women getting abortions.

Interestingly, $9 \%$ of Catholic subjects objected to terminating pregnancy in order to save the mother's life ( $82 \%$ approved and $9 \%$ were not sure). In the scenario presented, a woman with endometrial cancer has her uterus removed, and as a result, the fetus dies.
Whereas official Catholic teaching does not endorse abortion for raped women, it does excuse hysterectomies, even if the fetus dies. The rationale is that, in abortion, the fetus is directly targeted, whereas in hysterectomies, the intention is the removal of the uterus to save the woman; the death of the fetus is only an unintended side effect. Catholic theologians have long defended the doctrine of "double effect," according to which, actions that seek good results, yet have unfortunate side effects, are morally acceptable, as long as the side effects are not intended, and they are proportional to the goal of the original action. ${ }^{7}$

As for in vitro fertilization discarding embryos, $82 \%$ of Catholic subjects endorsed it, 18\% opposed it. Again, Catholic teaching is unmistakably clear on this: in vitro fertilization is not ethical. The rationale, again, is that discarding embryos amounts to killing a person, very much as in abortion. The same teaching applies to the use of embryonic stem cells: the concern for discarded embryos informs Catholicism's disapproval. Yet, in our sample, $73 \%$ of Catholics approved embryonic stem cell use and research, $18 \%$ opposed it, and $9 \%$ were not sure. Again, this is a rather surprising finding, as it does not correspond well with the emphasis Catholic doctrine places on rejecting in vitro fertilization and embryonic stem cell use.

Euthanasia has also been emphatically rejected by Catholic teaching. Catholicism upholds the sanctity of life, and thus, any initiative from doctors to assist in a patient's suicide is strongly rejected. In this regard, as opposed to cases of abortion and the discarding of embryos, Catholics in our sample seemed to be more in line with official teaching. About $55 \%$ of Catholic subjects thought that assisting a patient in suicide is immoral, $36 \%$ had no moral objections, and 9\% were not sure.

When encountered with the case of a military surgeon who administers morphine to a dying soldier in a battlefield, and the soldier dies, $45 \%$ of Catholic respondents ethically approved, $27 \%$ had moral objections, and $27 \%$ were not sure. As opposed to assisted suicide, in a case like this, Catholic doctrine has no moral objections. The relevant difference, again, is the doctrine of "double effect." In assisted suicide, the death of the patient is directly intended; in contrast, in this case of morphine administration, the death of the patient is only a side effect, but never originally intended.

In the questionnaire, two cases related to the doctrine of double effect: the case of the pregnant woman whose uterus is removed, and the case of the military surgeon who administers morphine. Sound moral reasoning would require that answers in both cases should be consistent (as they both rely on the same moral principle of "double effect"). Yet, among Catholics, only $45 \%$ had matching answers in both scenarios. 


\section{Muslims}

Very much as Protestants, and unlike Catholics, Muslims do not have a central authority that dictates religious or ethical doctrine, and this allows for great variation in interpretations of Scripture and moral teachings, probably much more than in any other religion. Yet, in the key moral issues addressed in the questionnaire (abortion and euthanasia), there is some general consensus among Muslim scholars.

As opposed to Catholicism, Islam does not have a specific doctrine teaching that the soul enters the body at the moment of fertilization. Instead, the spirit (rub) enters the fetus around 120 days after conception. For that reason, prior to the 4th month of pregnancy, abortion is not considered a wrong. Yet, Islam does not encourage abortion, and only allows it in very extreme cases. Specifically, "a medical diagnosis that detects a fetus to be severely deformed or defective, carrying a life threatening hereditary or untreatable disease, or afflicted with a serious handicap is not sufficient grounds for termination," but many Muslims allow abortion for family planning. ${ }^{8}$

When presented with case of woman into her 4 th week of pregnancy who decides to have an abortion for no particular reason, $44 \%$ of Muslim subjects accepted it, whereas $33 \%$ opposed it and $22 \%$ were not sure. This is contrary to the initial expectation. When it comes to abortion, Islam doctrinally is more lax than Catholicism and other branches of Christianity, and yet, Muslims respondents had higher representation in pro-life positions.

In the case of a raped woman, $67 \%$ of Muslim subjects agreed that the victim would have a moral right to abort, $11 \%$ disagreed, and 22\% were not sure. Muslim jurists debate whether abortion is morally acceptable in the case of rape. Some fatwas have been issued authorizing abortion for raped women, but some eminent jurists oppose it. ${ }^{9}$ This doctrinal disagreement is reflected well in the subjects' response.

About $89 \%$ of Muslim respondents had no moral objections to a hysterectomy on a pregnant woman to save her life, $11 \%$ did have moral objections. Again, this reflects well the Islamic doctrinal stand. Along with Catholic theologians, Medieval Islamic theologians developed the doctrine of "double effect,"10 and this teaching would excuse the medical procedure described in this scenario. Therefore, it is not surprising to find that the overwhelming majority of Muslim respondents morally approved it.

About $89 \%$ of Muslim subjects had no objections to in vitro fertilization discarding embryos, and $11 \%$ were not sure. This is expected, as Islamic teaching approves in vitro fertilization, as long as the sperm and egg come from spouses. Once again, let us recall that Islamic doctrine considers that the spirit enters the body 120 days after conception, and therefore, discarding embryos in assisted reproduction is not killing a person.

Yet, it is surprising to find out that $56 \%$ of Muslim subjects were not sure whether embryonic stem cell therapy and research is ethical, 33\% approved it, $11 \%$ opposed it. Since this is a new area of medical ethics that medieval theologians never thought about, there is no firm Islamic stand on stem cell research and therapy. But, most contemporary Muslim jurists approve it, again, on the rationale that prior to 120 days after conception, the embryo is not a person, and therefore, discarding embryos is not a moral wrong. ${ }^{11}$

When it comes to assisted suicide, $22 \%$ of Muslim subjects accepted it, $67 \%$ opposed it, and $11 \%$ were not sure. Very much as Christianity, Islam is emphatically against euthanasia, to the point that even passive euthanasia (withholding treatment with the patient's consent) is objected. Although support for euthanasia is low among Muslim respondents compared with other groups in this research (36\% in Catholics, $67 \%$ in atheists, $25 \%$ in Hindus, 57\% in Sikhs), it is still high, considering how emphatic Islamic doctrine is in condemning physicians who assist patients with suicide.

About $67 \%$ of Muslim subjects condemned a military surgeon administering morphine to a badly wounded soldier to relieve his pain, and as a result, the soldier dies; $11 \%$ morally approved and $22 \%$ were not sure. Very much as Catholics, there is some inconsistency here. As previously mentioned, Catholic and Muslim theologians jointly developed the doctrine of "double effect" and that doctrine would allow a doctor to administer morphine in that scenario. Morally, it is the same situation as a pregnant woman who gets a hysterectomy, as they are both excused under the principle of "double effect." Yet, among Muslim respondents, only 22\% matched their responses in both cases.

\section{Atheists}

Unlike members of other religious groups, atheists are usually not born into atheist families, and they become atheists out of their own will. That usually implies that they have given some thought to the coherence of religious doctrines and have come to the conclusion that they are false, as a result of rational deliberation.

This is somewhat reflected in the average time they took to respond the survey. Atheists took an average of 3 minutes and 40 seconds to respond, as opposed to, say, non-Catholic Christians, who took an average of 13:33. This short average time may reflect that, since atheists have given thought to religious and ethical doctrines, they are already sure of what they think. And, in fact, no atheist responded "not sure" in any of the questions. 
About $83 \%$ of atheist subjects believed that it would be morally acceptable for a woman to have an abortion, $17 \%$ disagreed. The pro-life/pro-choice divide tends to correspond with religious differences, but it is not a perfect correlation. In public opinion, most opposition to abortion comes from religious arguments, but that does not imply that all atheists are pro-choice.

When it comes to rape, $100 \%$ of atheists believed that abortion in the case of rape is ethically permissible. Also, $100 \%$ of atheists agreed that a hysterectomy to save a pregnant woman's life is morally admissible. Likewise, $100 \%$ of atheists had no moral objections to in vitro fertilization discarding embryos. However, $17 \%$ of atheists opposed the use of embryonic stem cell therapy, whereas $83 \%$ had no objections. Again, this seems to be inconsistent for that $17 \%$, that opposed stem cell research and therapy, as in both scenarios, embryos are discarded; so the moral reasoning to favor one procedure should also be enough to favor the other procedure.

As for euthanasia, $67 \%$ of atheist subjects approved the scenario of a doctor assisting a patient to commit suicide, 33\% opposed. Again, although the debate on euthanasia usually relies on religious arguments, there are plenty of non-religious arguments against euthanasia, and therefore, it is not entirely surprising that $33 \%$ of atheist subjects presented moral objections to euthanasia.

About $83 \%$ of atheists had no objections to a doctor administering morphine to alleviate the pain of a badly wounded soldier, causing his death as a side effect; $13 \%$ opposed the doctor's procedure. Traditionally, atheist ethicists have not paid much attention to the doctrine of "double effect." Yet, the fact that a higher percentage approved the case of the doctor administering morphine, than the case of a doctor actively assisting a patient to die, reflects some understanding of the principle that intentions have moral relevance. However, not all atheists were consistent in applying the principle of "double effect": $17 \%$ believed that a pregnant woman may get a hysterectomy to save her life, but the surgeon is unethical in administering morphine. Once again, let us recall that, under the principle of "double effect," both cases amount to the same judgment.

\section{Hindus}

Many Hindus claim that there is no such thing as Hinduism, that this is actually a Western category used to clump together very diverse beliefs and practices. There is some academic debate about how true this is, ${ }^{12}$ but be it as it may, it is definitely a fact that Hinduism's diversity is immense, and that there is nothing remotely close to centralized Hindu authority or even uniform Hindu doctrine. Nevertheless, there are still some relatively common beliefs.
When it comes to abortion, ancient dharma literature originally condemned it. But, as medical technologies were improved and abortions were more safely practiced, Hindus had a more tolerant approach toward abortion. However, in more recent times, abortions for gender selection have been alarmingly on the rise in India (boys are preferred over girls in Hindu society), and this has caused concern, thus winging the pendulum against abortion. $^{13}$

Very much as Catholics and unlike Muslims, Hindus traditionally believe that the soul and body are joined at conception. Hindus also traditionally believe in the doctrine of reincarnation, which implies that, since the fetus is already someone who has previously lived, it can already be considered a person, and therefore, abortion is wrong. Nevertheless, Hinduism is not as vehemently pro-life as Catholicism.

In our research, $63 \%$ of Hindu subjects approved of abortion, $25 \%$ opposed it, and $13 \%$ were not sure. However, in the case of a raped woman, $100 \%$ of Hindus agreed that it is morally acceptable to have an abortion. The fact that there has been a recent epidemic of rape in India may make Hindu respondents more sensitive about the needs of raped women (and that may be why $100 \%$ of respondents morally approved of raped women getting abortions), but on this point, we can only speculate. Hindu respondents also unanimously (100\%) agreed that, if there needs to be an abortion to save the mother's life (e.g., hysterectomy for endometrial cancer), then it is ethically acceptable.

About $25 \%$ of Hindu subjects opposed in vitro fertilization discarding embryos, $75 \%$ approved. As for embryonic stem cell research and therapy, $63 \%$ of Hindus approved, $25 \%$ opposed it, and $13 \%$ were not sure.

In Hindu doctrine, the principle of ahimsa is paramount. Ahimsa is roughly equivalent to nonviolence, and this supports the doctrine defending the sanctity of life. This has prompted notable Hindu spokespersons to condemn in vitro technology, if that implies discarding embryos.

However, given the rise of nationalist parties in India during the last decade, there is now a widespread belief that many modern-day technologies were already present in Ancient India. The story of Gandhari in the Mahabharata is usually interpreted by Hindus as if it refers to contemporary in vitro technology with divine help. ${ }^{14}$ There is therefore, some tension within Hinduism regarding in vitro technologies and the discarding of embryos, and this seems to be reflected in Hindu respondents' views.

Hinduism's approach to euthanasia is not entirely clear, either. There is some doctrinal opposition, on the grounds that "ending a life interferes with the cycle of death and rebirth and is thus opposed to karma.. ${ }^{15}$ Yet, in 
Hinduism there is also the view that it may be a duty to help a suffering person end her life. Again, this lack of a definite position on euthanasia reflects well the responses from Hindu subjects when asked about a doctor who assists a suffering patient in committing suicide; $25 \%$ agreed the doctor would be ethical, $50 \%$ believed the doctor would be unethical, and 25\% were not sure.

As for the question about a doctor who administers morphine to a badly wounded soldier in a battlefield to alleviate pain, and the soldier dies (again, strictly speaking, this is not euthanasia), $50 \%$ of Hindu subjects agreed the doctor would be ethical, 38\% disagreed, and $13 \%$ were not sure.

\section{Sikhs}

The Sikh religion is greatly concerned with ethics, as it views its own origins as a reform movement against the abuses of caste society in India. Yet, when it comes to the particulars of medical ethics, Sikhism does not have definite stands, and the Sikh Code of Conduct does not address these issues. Nevertheless, in general, Sikh doctrine opposes abortion. This is on the grounds that life begins at conception, as it is explicitly stated in the Guru Granth Sahib, Sikhism's holy book. ${ }^{16}$

It is thus somewhat surprising to find that $86 \%$ of Sikh respondents had no moral objection to a woman getting an abortion, for no particular reason; $14 \%$ opposed it. In the case of rape, $100 \%$ of Sikh subjects agreed that the victim may ethically get an abortion. Likewise, 100\% of Sikh respondents approved of an abortion to save the mother's life. Despite Sikh doctrine's opposition to abortion, these views are not entirely surprising, because in the Punjab (the demographic stronghold of Sikhism), abortion is relatively common, especially for purposes of gender selection. ${ }^{17}$

Regarding in vitro fertilization discarding embryos, $71 \%$ of Sikh respondents morally approved, $14 \%$ opposed it, and $14 \%$ were not sure. The exact same results came when considering stem cell therapy and research that, again, discard embryos. This corresponds well with the general trend in the global Sikh community, which leans toward openness to reproductive and medical technologies. $^{18}$

The doctrinal Sikh stand on euthanasia is firmer, and it generally condemns it. Sikhism teaches that, as long as there is life, there is hope, and "Sikhs contemplating euthanasia era encouraged to look at the whole of life and try to make the appropriate distinctions between ending life and not artificially prolonging a terminal state." This view fits well with Sikh respondents' reactions to the case of a doctor who assists a patient in suicide. Whereas the support for abortion was high (86\%), only 57\% of Sikhs respondents morally excused the hypothetical doctor, $28 \%$ condemned the doctor, and $14 \%$ were not sure.

The Sikh ethos has been historically embedded in the military profession. Historically, Sikhs developed a big reputation for being extremely brave and loyal soldiers. In the military ethos, the principle of double effect is standard. We may therefore, have the mild expectation that Sikh respondents would not object to a military surgeon administering morphine to a badly wounded soldier in the battlefield to alleviate pain, and as a result, the soldier dies. However, $71 \%$ of Sikh respondents morally condemned the hypothetical doctor, and only $28 \%$ approved.

\section{Buddhists}

In our research, there was only one Buddhist subject. This is obviously not enough to make any meaningful statement. Western and Japanese Buddhists tend to support abortion, Buddhists from elsewhere in Asia generally do not. ${ }^{19}$ The Buddhist subject objected to abortion, but allowed it for rape victims, and also in the case where the mother's life is in danger. The respondent also objected to in vitro technology discarding embryos, but did not oppose embryonic stem cell research and therapy.

In general, Buddhist doctrine opposes euthanasia, because it may cause bad karma. The Buddhist respondent condemned euthanasia, and the case of a doctor who administers morphine to a badly wounded soldier to alleviate pain, and causing death as a side effect.

\section{CONCLUSION}

At the onset of this investigation, we had the expectation that subjects would offer responses that were generally consistent with their religious affiliation. That is why, in the research design, religious affiliation would be the independent variable, and medical ethical opinions would be the dependent variable, as it was expected that religion would determine ethical opinions. However, that did not turn out to be the case in most scenarios. Of all groups, Muslim subjects' ethical opinions were most consistent with the doctrine of their religious affiliation, whereas Catholic subjects' ethical opinions were the least consistent with the doctrine of their religious affiliation. This may confirm the observation made by many sociologists of religion, according to which Catholic societies are currently more secularized than Muslim societies. ${ }^{20}$

It also became clear that, as a whole, the subjects' moral reasoning was somewhat inconsistent. Subjects struggled to understand the moral similarity between the case of an abortion to save a mother's life, and the case of a military surgeon administering morphine to alleviate the pain of a dying soldier. In both scenarios, the moral principle of "double effect" is applicable, but overall, only 
$30 \%$ had consistent answers. This may reflect the need for curricular committees at Xavier University School of Medicine, Aruba, to make sure that this moral principle is understood by students in Ethics courses, as it is a cornerstone of ethical practice in the medical profession.

\section{REFERENCES}

1. Wiley, J. Theory and practice in the philosophy of David Hume. New York: Palgrave McMillan; 2012.

2. Hamid, A. G.E. Moore. New York: Mittal Publications; 1985.

3. Sarin, I. The global vision: Karl Jaspers. Detroit (MI): Peter Lang AG; 2009.

4. Swanson, E. Abortion poll: vast majority support legal abortion for rape victims. Gurugram: Huffpost; 2012. [cited 2012 Oct 31]. Available from: http://www.huffingtonpost. com/2012/10/31/abortion-poll-legal-access-rape-victims_ n_2044973.html.

5. Flinn, F. Encyclopedia of Catholicism. New York: Facts On File; 2007.

6. Allen, J. The catholic church: what everyone needs to know. Oxford: Oxford University Press; 2013.

7. Walsh, M. Roman Catholicism: the basics. New York: Routledge; 2005.

8. Ebrahim, M. Ethics and social issues. In: Martin RC, editor. Encyclopedia of the Islam and the Muslim world. New York: Macmillan; 2004.
9. BBC. “Abortion. Islam” BBC. Religions. 2009. [cited 2009 Sep 7]. Available from: http://www.bbc.co.uk/religion/religions/ islam/islamethics/abortion_1.shtml.

10. Kelsey, J. Islam and war: a study in comparative ethics. New York: Westminster John Knox Press; 1993.

11. Barry, V. Bioethics in a cultural context: philosophy, religion, history, politics. Toronto: Cengage Learning; 2011.

12. Muesse, W. Great world religions: Hinduism. New York: W.W. Norton; 2003.

13. Lotchefeld, JG. The illustrated encyclopedia of Hinduism: a-m. New York: Rosen Publishing Group; 2002.

14. Crawford, SC. Hindu bioethics for the twenty-first century. New York: SUNY Press; 2003.

15. Pappu, S. Hindu ethics. In: Rinehart R, editor. Contemporary Hinduism: ritual, culture, and practice. Oxford: ABC Clio; 2004. pp. 150-180.

16. Singh, P. The Guru Granth Sahib and Sikhism. Delhi: Oxford University Press; 2003.

17. Skolnik, R. Global health 101. 2nd ed. New York: Jones \& Bartlett Publishers; 2011.

18. Mandair, A. Sikhism. In: Sorajjakool S, Carr C, Nam J, editors. World religions for healthcare professionals. London: Routledge; 2009.

19. Hughes, J. Buddhism and abortion: a western approach. In: Keown D, editor. Buddhism and abortion. New York: Springer; 2016.

20. Warner, R. Secularization and its discontents. London: A\&C Black; 2010. 